\title{
Kolaborasi Messessaba (Media Feses Sapi dan Feses Domba) terhadap Respon Cacing Tanah (Pheretima Sp)
}

\author{
I. R. Dani, Jarmuji, A. W. N. Pratama, dan D. A. Nugraha \\ Jurusan Peternakan, Fakultas Pertanian, Universitas Bengkulu \\ Jalan W.R. Supratman Kandang Limun Bengkulu 38371A \\ Email: icukr19@gmail.com
}

\begin{abstract}
This study aimed to evaluate cow feces and sheep as media for earthworm's (Pheretima, $s p$ ) growth and mortality. The design used in this study was Completely Random Design (CRD) consisting of 5 treatments and 5 replications, each replication containing of 10 earthworms Pheretima, $s p$ aged 2-3 days with the treatment given were: $\mathrm{P} 1=50 \%$ rice husk $+50 \%$ feces $(100 \%$ cow feces $), \mathrm{P} 2=50 \%$ rice husk $+50 \%$ feces $(75 \%$ cow feces + $25 \%$ sheep feces $), \mathrm{P} 3=50 \%$ rice husk $+50 \%$ feses $(50 \%$ cow feces $+50 \%$ sheep feces $), \mathrm{P} 4=50 \%$ rice husk + $50 \%$ feces $(25 \%$ cow faeces $+75 \%$ sheep feces $)$, P $5=50 \%$ husk Rice $+50 \%$ feses $(100 \%$ sheep feces $)$. The results showed that the higher used of sheep feces can reduce weight gain and increase the mortality of earthworms (Pheretima sp). The use of $100 \%$ cow feces as a media produced the best growth of all treatments.
\end{abstract}

Key words : earthworm, growth, media ratio, mortality

\begin{abstract}
ABSTRAK
Penelitian ini bertujuan untuk mengevaluasi imbangan feses sapi dan domba sebagai media untuk pertumbuhan dan mortalitas cacing tanah (Pheretima sp). Rancangan yang digunakan dalam penelitian ini yaitu Rancangan Acak Lengkap (RAL) yang terdiri dari 5 perlakuan dan 5 ulangan, masing-masing ulangan berisi 10 ekor cacing tanah Pheretima sp berumur 2-3 hari dengan perlakuan yang diberikan antara lain ; P1 $=50 \%$ sekam padi $+50 \%$ feses $(100 \%$ feses sapi), $\mathrm{P} 2=50 \%$ sekam padi $+50 \%$ feses $(75 \%$ feses sapi $+25 \%$ feses domba $), \quad \mathrm{P} 3=50 \%$ sekam padi $+50 \%$ feses $(50 \%$ feses sapi $+50 \%$ feses domba $), \mathrm{P} 4=50 \%$ sekam padi $+50 \%$ feses $(25 \%$ feses sapi $+75 \%$ feses domba), P5 $=50 \%$ sekam padi $+50 \%$ feses $(100 \%$ feses domba). Hasil penelitian menunjukkan bahwa semakin tinggi penggunaan feses domba dapat menurunkan pertambahan bobot badan dan meningkatkan mortalitas cacing tanah (Pheretima sp). Penggunaan $100 \%$ feses sapi sebagai media menghasilkan pertumbuhan terbaik dari semua perlakuan.
\end{abstract}

Kata kunci: cacing tanah, pertumbuhan, imbangan media, mortalitas

\section{PENDAHULUAN}

Cacing tanah merupakan hewan tingkat rendah karena tidak memiliki tulang belakang (invertebrata) serta mempunyai bentuk yang lunak dan tergolong kedalam filum Annelida atau tersusun atas beberapa segmen (ruas) dengan bentuk seperti cincin (Khairuman dan Amri, 2009). Menurut Hermawan (2014), manfaat cacing tanah seperti menyuburkan lahan pertanian, sebagai bahan baku obat, bahan baku kosmetik, makanan manusia dan bahan pakan ternak.
Kandungan gizi pada cacing tanah sangatlah tinggi dibandingkan dengan tepung ikan. Kadar protein cacing tanah berkisar antara 64-76\%, sedangkan tepung ikan hanya memiliki kandungan protein sekitar 58\%, selain itu memiliki kadar lemak yang cukup rendah sekitar 7-10\% serta kandungan lain yang terdapat pada cacing tanah diantarnya $0,55 \%$ kalsium, $1 \%$ fosfor, dan 1,08\% serat kasar (Maulida, 2015).

Komposisi tubuh cacing tanah (Pheretima $s p$ ) hampir seluruhnya terdiri dari air. Menurut Sihombing (2002), 
sebanyak 75-90\% dari berat tubuh cacing tanah berupa air sehingga sangat sensitif pada sinar matahari. Cacing tanah apabila terlalu lama terpapar sinar matahari dapat menyebabkan cacing tanah mati (Maulida, 2015). Lee (1985) mengemukakan bahwa cacing tanah (Pheretima $s p$ ) membutuhkan kondisi media yang sesuai dan berkecukupan pakan, terlindungi dari cahaya, $\mathrm{pH}$ sekitar netral serta sirkulasi udara dan air yang baik. Menurut Roslim et al. (2013), media pertumbuhan yang sesuai akan mendukung pertumbuhan cacing tanah. Maulida (2015), menyatakan syarat hidup cacing tanah (Pheretima $s p$ ) dipengaruhi oleh beberapa faktor diantaranya kelembaban, suhu, ketersediaan zat organik, keasaman $(\mathrm{pH})$.

Saat ini peternak cacing tanah (Pheretima sp) sudah menggunakan kotoran sapi sebagai media tumbuh cacing tanah. Menurut Maulida (2015), kotoran sapi memiliki banyak zat organik sehingga bagus untuk pertumbuhan cacing tanah. Hanafiah et al. (2010) disitasi Roslim (2013) melaporkan penggunaan media kotoran sapi lebih disukai cacing tanah dibandingkan kotoran hewan ternak yang lain karena mengandung unsur nitrogen yang tinggi, tetapi ada kendala apabila langsung digunakan tanpa dilakukan pengeringan. Pengeringan kotoran sapi dilakukan dengan tujuan menghilangkan kandungan amonia yang beresiko meracuni cacing tanah (Pheretima sp) sehingga dapat menyebabkan kematian (Maulida, 2015).

Saat ini kotoran domba jarang digunakan sebagai media pemeliharaan cacing tanah. Kandungan hara yang terdapat pada kotoran domba mengandung $1,28 \%$ nitrogen, 0,19 fosfor, $0,93 \%$ kalium, 0,59\% calsium, $0,19 \%$ magnesium, $0,09 \%$ sulfur, 0,020 besi (Tan, 2009). Resnawati dan Asmarasari (2007) dalam penelitiannya mengemukakan pemberian media kotoran domba dan media serabut kelapa dengan taraf 1:1 dari umur 3 - 4 bulan dapat memberikan penampilan yang optimum pada cacing tanah, sehingga memungkinkan digunakan sebagai media tumbuh cacing tanah (Pheretima sp).

Dari kedua limbah peternakan yaitu feses sapi dan feses domba terdapat kandungan nutrisi yang dibutuhkan untuk pertumbuhan cacing tanah sehingga perlu dilakukan penelitian tentang imbangan feses sapi dan feses domba yang disuplementasikan dengan sekam padi terhadap pertumbuhan cacing tanah (Pheretima sp).

\section{MATERI DAN METODE}

Penelitian ini dilaksanakan selama 2 bulan mulai 25 Maret - 22 Juni 2017. Lokasi yang digunakan adalah Kandang Jurusan Peternakan Universitas Bengkulu dan lokasi budidaya cacing tanah (Pheretima $s p$ ) di Gang Juwita Kiri sebagai lokasi pembibitan.

Peralatan yang digunakan dalam penelitian ini, yaitu 25 buah ember plastik, timbangan digital, termometer ruang, termometer media, soiltester, karung plastik, cangkul, botol semprot, kamera dan alat tulis. Bahan - bahan yang digunakan adalah 250 ekor cacing tanah 
(Pheretima sp) umur 2-3 hari, feses sapi bali, feses domba, sekam padi, kapur dan air bersih.

\section{Persiapan Ruangan Penelitian}

Tahapan persiapan penelitian dilakukan dengan ruangan terbuka tanpa terkena cahaya matahari dan suhu ruangannya $25^{\circ} \mathrm{C}-30^{\circ} \mathrm{C}$ kemudian ruangan tersebut berfungsi untuk meletakkan ember yang nantinya akan ditanami dengan ditempati secara hamparan.

\section{Pengadaan cacing tanah Pheretima sp}

Sebelum penelitian dilakukan maka perlu pengadaan bibit cacing tanah Pheretima $s p$ dengan cara memelihara cacing tanah Pheretima $s p$ dewasa sampai menghasilkan anak. Selanjutnya, anak yang berumur 2 - 3 hari diambil sebanyak 250 ekor sebagai bahan penelitian. Cacing tanah yang berumur 2-3 hari mempunyai ciri-ciri cacing tanah masih berkumpul di sekitar kokon.

\section{Persiapan Media}

Media yang digunakan dalam penelitian ini adalah feses sapi dan feses domba yang dicampur dengan sekam padi sebanyak 50\%. Persiapan media dilakukan dengan menghancurkan feses domba kemudian mencampurkan dengan kotoran sapi dan media ditambahkan kapur dengan air secukupnya, kira-kira kadar air mencapai 60\% (Brata, 2003). Selanjutnya mengambil feses sapi dan feses domba untuk dikeringanginkan serta dilakukan penyisiran dengan tujuan menghilangkan benda-benda anorganik. Media diaduk dan ditaburi kapur sebanyak $0,2 \%$ dari media hingga merata sambil diberi air bersih sebanyak $60 \%$ dan difermentasikan menggunakan kantong plastik selama 21 hari untuk menghilangkan gas-gas yng tidak dikehendaki seperti gas methan (Waluyo, 1993). Media yang digunakan terlebih dahulu dilakukan uji $\mathrm{N}$ sebelum media diberikan perlakuan cacing tanah. Perhitungan kebutuhan media didasarkan pada bobot badan dewasa cacing tanah (a gram), lama pemeliharaan (b hari), dan kebutuhan cacing tanah terhadap pakan dihitung sebanyak 3 kali bobot badan. Perhitungan kebutuhan media sebagai pakan cacing dapat dihitung menurut Brata (2003) : Y gram =a gram x b x 3.

\section{Persiapan Penelitian dan Pemeliharaan Cacing Tanah}

Dari masing - masing ember yang telah diisi media kemudian dimasukan 10 ekor cacing tanah Pheretima sp umur 2-3 hari dengan cara membuat lubang ditengah - tengah media dengan kedalaman $5 \mathrm{~cm}$ kemudian lubang ditutup. Tempat pemeliharaan ditutup dengan menggunakan kain dan memberi kode pada setiap ember. Penyiraman dilakukan sekali dalam 3 hari kemudian mengembalikan media (Brata, 2003).

\section{Rancangan Penelitian}

Penelitian ini menggunakan rancangan acak lengkap (RAL) dengan 5 perlakuan dan 5 ulangan. Setiap perlakuan menggunakan 50\% sekam padi dan 50\% feses (feses sapi dan feses domba) dengan jumlah imbangan feses yang diberikan 
setiap perlakuan berbeda. Setiap ulangan ditanami 10 ekor bibit cacing tanah Pheretima sp umur 2-3 hari. Cacing yang digunakan dalam penelitian ini sebanyak 250 ekor dengan perlakuan berikut.

Tabel 1. Kandungan nitrogen media feses sapi dan feses domba

\begin{tabular}{cccccc}
\hline \multirow{2}{*}{ Kandungan } & \multicolumn{5}{c}{ Perlakuan } \\
\cline { 2 - 6 } & $\mathrm{P} 1$ & $\mathrm{P} 2$ & $\mathrm{P} 3$ & $\mathrm{P} 4$ & $\mathrm{P} 5$ \\
\hline $\mathrm{N}(\%)$ & 0,73 & 0,85 & 0,60 & 0,57 & 0,60
\end{tabular}

Sumber : Hasil Analisis Laboratorium Ilmu Tanah Fakultas Pertanian Universitas Bengkulu 2017

Keterangan $: \mathrm{P} 1=50 \%$ sekam padi $+50 \%$ feses $(100 \%$ feses sapi).

$$
\begin{aligned}
& \mathrm{P} 2=50 \% \text { sekam padi }+50 \% \text { feses }(75 \% \text { feses sapi }+25 \% \text { feses domba }) \\
& \mathrm{P} 3=50 \% \text { sekam padi }+50 \% \text { feses }(50 \% \text { feses sapi }+50 \% \text { feses domba) } \\
& \mathrm{P} 4=50 \% \text { sekam padi }+50 \% \text { feses }(25 \% \text { feses sapi }+75 \% \text { feses domba). } \\
& \mathrm{P} 5=50 \% \text { sekam padi }+50 \% \text { feses }(100 \% \text { feses domba })
\end{aligned}
$$

\section{Variabel yang Diamati}

Dalam penelitian ini, variabel yang diamati adalah pertambahan bobot badan.

\section{Pertambahan Bobot Badan Induk}

Bobot badan cacing tanah (Pheretima $s p$ ) dihitung dan dilakukan penimbangan pada awal dan akhir pemeliharaaan 60 hari. Teknik pengukuran dilakukan dengan membersihkan seluruh induk dari kotoran media dan dimasukan kedalam kantong plastik kecil ukuran $15 \times 10 \mathrm{~cm}$ kemudian dilakukan penimbangan. Selanjutnya hasil penimbangan dikurangi dengan berat plastik.

Pada pengukuran pertambahan bobot badan cacing tanah (Pheretima $s p$ ) dapat dihitung dengan menggunakan rumus sebagai berikut :

PBB = bobot badan akhir - bobot badan awal

\section{Mortalitas}

Pengamatan parameter mortalitas induk dilakukan berdasarkan jumlah total kematian induk cacing tanah per unit pemeliharaan. Pengamatan dilakukan sekali yaitu di akhir penelitian.

\section{Analisis Data}

Semua data yang diperoleh dianalisis secara stastistik dengan menggunakan analisis varians. Apabila ada perbedaan nyata maka akan dilanjutkan dengan Uji Jarak Berganda Ducan's (Ducan's Multiple Range test/DMRT) untuk mengetahui perbedaan antara lima perlakuan (Yitnosumarto,1993).

\section{HASIL DAN PEMBAHASAN}

\section{Pertambahan bobot badan induk}

Rataan pertambahan bobot badan induk cacing tanah Pheretima $s p$ yang dipelihara dengan menggunakan media feses sapi dan feses domba dengan menggunakan 5 perlakuan. 
Tabel 2. Rataan pertambahan bobot badan induk cacing tanah Pheretima sp selama 60 hari

\begin{tabular}{ccccccc}
\hline \multirow{2}{*}{ Perlakuan } & \multicolumn{5}{c}{ Ulangan } & \multirow{2}{*}{ Rataan } \\
\cline { 2 - 5 } & 1 & 2 & 3 & 4 & 5 & \\
\cline { 1 - 4 } P1 & 0,85 & 0,77 & 0,95 & 0,81 & 0,86 & $0,85 \pm 0,07^{\mathrm{a}}$ \\
P2 & 0,86 & 0,64 & 0,80 & 0,70 & 0,76 & $0,75 \pm 0,09^{\mathrm{b}}$ \\
P3 & 0,58 & 0,70 & 0,56 & 0,72 & 0,59 & $0,63 \pm 0,07^{\mathrm{c}}$ \\
P4 & 0,64 & 0,58 & 0,57 & 0,56 & 0,51 & $0,57 \pm 0,05^{\mathrm{c}}$ \\
P5 & 0,47 & 0,42 & 0,47 & 0,47 & 0,54 & $0,47 \pm 0,04^{\mathrm{d}}$ \\
\hline
\end{tabular}

Keterangan: Superskrip yang berbeda pada kolom yang sama menunjukkan sangat berbeda nyata $(\mathrm{P}<0,01)$. Keterangan $: \mathrm{P} 1=50 \%$ sekam padi $+50 \%$ feses (100\% feses sapi).
$\mathrm{P} 2=50 \%$ sekam padi $+50 \%$ feses $(75 \%$ feses sapi $+25 \%$ feses domba).
$\mathrm{P} 3=50 \%$ sekam padi $+50 \%$ feses $(50 \%$ feses sapi $+50 \%$ feses domba).
$\mathrm{P} 4=50 \%$ sekam padi $+50 \%$ feses $(25 \%$ feses sapi $+75 \%$ feses domba $)$.
$\mathrm{P} 5=50 \%$ sekam padi $+50 \%$ feses $(100 \%$ feses domba $)$.

Berdasarkan hasil analisis ragam menunjukkan pemberian media feses sapi dan feses domba berpengaruh sangat nyata $(\mathrm{P}<0,01)$ terhadap pertambahan bobot badan induk cacing tanah Pheretima $s p$. Rataan partambahan bobot badan induk cacing tanah disajikan pada Tabel 2. Masing - masing perlakuan $\mathrm{P} 1=0,85 \mathrm{~g} / \mathrm{unit}$, $\mathrm{P} 2=0,75 \mathrm{~g} / \mathrm{unit}, \mathrm{P} 3=0,63 \mathrm{~g} / \mathrm{unit}, \mathrm{P} 4=$ $0,57 \mathrm{~g} / \mathrm{unit}$, dan P5 = 0,47 g/unit. Adanya perbedaan pada masing - masing unit perlakuan mungkin disebabkan oleh kandungan $\mathrm{N}$ yang berbeda di setiap perlakuan. Selain itu mungkin dapat dipengaruhi oleh jumlah komposisi media yang berbeda beda di setiap unit perlakuan. Hasil analisis uji $\mathrm{N}$ media diperoleh data pada masing - masing perlakuan $\mathrm{P} 1=$ $0,73 \%, \mathrm{P} 2=0,85 \%, \mathrm{P} 3=0,60 \%, \mathrm{P} 4=$ $0,57 \%$ dan P5 $=0,60 \%$. Menurut Roslim (2013), cacing tanah yang mengkonsumsi pakan yang kaya nitrogen akan mengalami pertumbuhan bobot badan yang cepat dan menghasilkan kokon yang tinggi.

Berdasarkan uji lanjut Ducan Multiple Range Test (DMRT) memperlihatkan perlakuan $\mathrm{P} 1 ; 0,85 \mathrm{~g} / \mathrm{unit}$ berbeda sangat nyata $(\mathrm{P}<0,01)$ terhadap perlakuan P2; 0,75 g/unit,P3; 0,63 g/unit, P4; 0,57 g/unit dan P5; 0,47 g/unit. Kemudian pada perlakuan P2; 0,75 g/unit berbeda sangat nyata $(\mathrm{P}<0,01)$ terhadap perlakuan P3; 0,63 g/unit, P4; 0,57 g/unit dan P5; 0,47 g/unit. Selanjutnya pada perlakuan P3; 0,63 g/unit tidak berbeda nyata $(\mathrm{P}<0,05)$ terhadap perlakuan $\mathrm{P} 4 ; 0,57$ g/unit tetapi berbeda sangat nyata $(\mathrm{P}<0,01)$ terhadap perlakuan $\mathrm{P} 1 ; 0,85 \mathrm{~g} / \mathrm{unit}, \mathrm{P} 2$; 0,75 g/unit, dan P5; 0,47 g/unit. Kemudian pada perlakuan $\mathrm{P} 5 ; 0,47 \mathrm{~g} / \mathrm{unit}$ berbeda sangat nyata $(\mathrm{P}<0,01)$ terhadap perlakuan $\mathrm{P} 1 ; 0,85$ g/unit, P2; 0,75 g/unit, P3; 0,63 g/unit dan P4; 0,57 g/unit.

Hasil penelitian menunjukkan rataan pertambahan bobot badan cacing tanah (Pheretima $s p$ ), tertinggi pada perlakuan $\mathrm{P} 1 ; 0,85 \mathrm{~g} / \mathrm{unit}$ sedangkan rataan terendah pada perlakuan P5; 0,47 g/unit. Kandungan $\mathrm{N}$ sebanyak $0,73 \%$ yang terdapat dalam media dengan imbangan $100 \%$ feses sapi memberikan pertambahan bobot badan tertinggi dibandingkan dengan yang 
lainnya. Berdasarkan analisis N, kandungan nitrogen pada perlakuan $\mathrm{P} 1$; $0,73 \%$ lebih rendah dibandingkan dengan perlakuan $\mathrm{P} 2 ; 0,85 \%$, akan tetapi pertambahan bobot badan induk perlakuan P2; 0,75 g/unit lebih rendah dibandingkan dengan perlakuan P1; 0,85 g/unit. Hal ini menunjukkan bahwa tidak hanya kandungan nitrogen yang dapat mempengaruhi bobot badan induk cacing tanah tetapi faktor lain seperti imbangan media dapat mempengaruhi pertambahan bobot badan induk cacing tanah (Pheretima $s p$ ).

Pertumbuhan cacing tanah (Pheretima $s p$ ) dimulai dari kokon, cacing muda (juvenil), cacing produktif dan cacing tua (Palungkung, 1999). Lama pertumbuhan cacing dipengaruhi oleh kondisi lingkungan, cadangan makanan dan jenis cacing tanah (Putra, 1999; Brata, 2009). Produksi cacing tanah sangat dipengaruhi oleh media yang digunakan dan pakan yang diberikan dalam proses pertumbuhan dan perkembangbiakan (Haryono, 2003). Menurut Annas (1990), aerasi yang baik dapat meningkatkan tekanan oksigen ke dalam media sehingga
$\mathrm{CO}_{2}$ akan lebih mudah keluar dari dalam media. Pemberian media berupa feses sapi local kaur yang diberikan pakan campuran pelepah sawit, rumput setaria dan pakan suplemen sakura block mempengaruhi pertumbuhan cacing tanah (Pheretima $s p$ ) seperti pertambahan bobot badan induk dan produksi bio massa (Jarmuji et al., 2015) serta mempengaruhi perkembangbiakan cacing tanah (Pheretima sp) seperti produksi anak (Jarmuji et al., 2017).

\section{Mortalitas Induk (ekor/unit)}

Rataan mortalitas cacing tanah Pheretima $s p$ yang dipelihara dengan menggunakan media feses sapi dan feses domba dengan menggunakan 5 perlakuan adalah $\mathrm{P} 1=50 \%$ sekam padi $+50 \%$ feses (100\% feses sapi), P2 $=50 \%$ sekam padi + $50 \%$ feses $(75 \%$ feses sapi $+25 \%$ feses domba), $\mathrm{P} 3=50 \%$ sekam padi $+50 \%$ feses (50\% feses sapi $+50 \%$ feses domba), $\mathrm{P} 4=50 \%$ sekam padi $+50 \%$ feses $(25 \%$ feses sapi $+75 \%$ feses domba), P5 $=50 \%$ sekam padi $+50 \%$ feses $(100 \%$ feses domba).

Tabel 3. Rataan mortalitas cacing tanah Pheretima sp selama 60 hari

\begin{tabular}{|c|c|c|c|c|c|c|}
\hline \multirow{2}{*}{ Perlakuan } & \multicolumn{5}{|c|}{ Ulangan } & \multirow{2}{*}{ Rataan } \\
\hline & 1 & 2 & 3 & 4 & 5 & \\
\hline \multicolumn{7}{|c|}{-----------------------ekor/unit------------------- } \\
\hline $\mathrm{P} 1$ & 0 & 0 & 0 & 0 & 0 & $0,00 \pm 0,00$ \\
\hline $\mathrm{P} 2$ & 0 & 0 & 0 & 0 & 0 & $0,00 \pm 0,00$ \\
\hline P3 & 0 & 0 & 0 & 1 & 1 & $0,40 \pm 0,55$ \\
\hline P4 & 2 & 1 & 0 & 2 & 1 & $1,20 \pm 0,84$ \\
\hline P5 & 2 & 3 & 2 & 2 & 1 & $2,00 \pm 0,71$ \\
\hline Jumlah & 4 & 4 & 2 & 5 & 3 & 3,60 \\
\hline
\end{tabular}


Adanya mortalitas pada perlakuan P3, P4 dan P5 disebabkan oleh semakin tingginya penggunaan media feses domba. Hal ini berhubungan dengan rasio $\mathrm{C} / \mathrm{N}$ dalam media feses domba. Rasio $\mathrm{C} / \mathrm{N}$ yang baik pada media tumbuh cacing tanah adalah $<20 \%$. Apabila rasio $\mathrm{C} / \mathrm{N}>20 \%$ maka akan menyebabkan cacing tanah kurang menyukai media. semakin rendah rasio $\mathrm{C} / \mathrm{N}$ dalam media maka akan semakin baik. Hal ini disebabkan karena media tersebut sudah terdekomposisi dengan baik sehingga cacing tanah akan menyukai media tersebut. Kadar C dalam media digunakan oleh cacing tanah untuk kebutuhan mikroorganisme didalam tubuh cacing tanah. sedangkan kadar $\mathrm{N}$ yang terdapat dalam media digunakan oleh cacing tanah untuk kebutuhan energi.

\section{KESIMPULAN}

Hasil penelitian menunjukkan bahwa pemberian media $50 \%$ sekam padi $+50 \%$ feses (100\% feses sapi) dan $50 \%$ sekam padi +50 feses $(75 \%$ feses sapi + $25 \%$ feses domba) meningkatkan pertambahan bobot Cacing Tanah (Pheretima $s p$ ) serta tingkat mortalitas yang rendah. Semakin tinggi penggunaan persentase feses domba dalam media maka kandungan $\mathrm{N}$ dalam media menjadi rendah dan mortalitas menjadi meningkat.

\section{UCAPAN TERIMAKASIH}

Terimakasih saya sanjungkan
kepada beberapa pihak yang telah
membantu dalam penelitian dan

terkhususnya pembuatan jurnal ini. Terimakasih untuk KEMRISTEK DIKTI yang telah memberikan dana kegiatan Tim Penelitian PKM 5 Bidang tahun 2016, Universitas Bengkulu.

\section{DAFTAR PUSTAKA}

Annas, I. 1990. Metode Penelitian Cacing Tanah dalam Nematoda. Departemen Pendidikan dan Kebudayaan. Direktorat Jendral Pendidikan Tinggi. Pusat Antar Universitas Bioteknologi. Institut Pertanian Bogor. Bogor.

Astuti, D. N. 2001. Pertumbuhan dan Perkembangbiakan Cacing Tanah Rumbricus rubellus dalam Media Kotoran Sapi yang Mengandung Tepung Darah. Skripsi. Fakultas Kedokteran Hewan Intitut Pertanian Bogor. Bogor.

Brata, B. 2003. Pertumbuhan, Perkembangan dan Kualitas Kasting dari Beberapa Spesies Cacing Tanah pada Kondisi Lingkungan yang Berbeda. Disertasi. Program Pasca Sarjana institut Pertanian Bogor. Bogor.

Brata, B. 2009. Cacing Tanah. IPB Press, Bogor.

Febrita, E., Darmadi dan E. Siswanto. 2015. Pertumbuhan Cacing Tanah (Lumbricus rubellus) dengan Pemberian Pakan Buatan untuk Mendukung Proses Pembelajaran pada Konsep Pertumbuhan dan 
Perkembangan Invertebrata. Jurnal Biogenesis. 2(2) : 169-176.

Harmatang, S. 2014. Isolasi dan Karekateristik Bakteri Simbion pada Cacing Tanah Pheretima sp dari Berbagai Substrat. Skripsi. Fakultas Matematika dan Ilmu Pengetahuan Alam. Universitas Hasanuddin. 2014.

Haryono. 2003. Pemanfaatan Serbuk Sabut Kelapa dan Ampas Tahu sebagai Media Pakan Cacing Tanah (Lumbricus rubellus). Prosiding Temu Teknis Fungsional Non Peneliti, Bogor. Pusat Penelitian dan Pengembangan Peternakan. 66-73.

Hayanti. 2006. Pengaruh Pemberian Serbuk Gergaji sebagai Campuran Media terhadap Produktivitas Cacing Tanah Pheretima sp. Skripsi. Program Studi Produksi Ternak. Jurusan Peternakan. Universitas Bengkulu. Bengkulu.

Hermawan, R. 2014. Usaha Budidaya Cacing Lumbricus Multiguna dan Prospek Ekspor Tinggi. Cetakan 2014. Pustaka Baru Press. Yogyakarta.

Jagjit, K. 2012. Jenis-jenis Cacing Tanah. http//:www.klutikjagjit.blogspot.c om/2011/. Diakses pada Tanggal 13 Oktober 2016, Pukul 02:58 WIB.
Jarmuji, B. Brata., U. Santoso and Karyono. 2015. Effect of Feces of Kaur Beef Fed Palm Frond, Setaria and Sakura Block as Media on Growth of Earthworm (Pheretima $s p$ ). Proceedings Iseprocal. Agriculture Faculty, Bengkulu University.

Jarmuji., U. Santoso and B. Brata. 2017. The Effect of Palm Oil Fronds as Setaria Substitution Plus Sakura Block on Performance and Nutrient Digestibilies in Kaur Cattles. Pak. J. Nutr., 16:200-206.

Khairuman dan K. Amri. 2009. Mengeruk Untung dari Beternak Cacing Tanah. Edisi Cetakan Pertama. PT Agromedia Pustaka. Jakarta.

Lee, K. E. 1985. Earthworm their Ecology and Relationships With Soila and Land Use. CSIRO Division of Soil Adelaide. Academic Press (Harcourt Brace Jovanovich Publishers), Sydney.

Maulida, A, A, A. 2015. Budidaya Cacing Tanah Unggul Ala Adam Cacing. Penerbit PT Agro Media. Jakarta Selatan.

Palungkung, R. 1999. Sukses Beternak Cacing Tanah Lumbricus rubellus. Penebar Swadaya, Jakarta. 1-80.

Putra. F.A. 1999. Hidup Bersama Cacing. Jakarta : Penebar Swadaya.

Resnawati, H dan Asmarasari, A. S. 2007. Respon Cacing Tanah (Lumbricus 
rubellus) terhadap Pemberian

Taraf Kotoran Domba dalam Media Serbuk Sabut Kelapa. Balai Penelitian Ternak. Bogor.

Roslim, D. I., Nastiti, D. S. dan Herman. 2013. Karakter Morfologi dan Pertumbuhan Tiga Jenis cacing Tanah Lokal Pekanbaru pada Dua Macam Media Pertumbuhan. Journal Biosantifika. Jurusan Biologi Fakultas Matematika dan Ilmu Pengetahuan Alam. Universitas Riau. Indonesia.

Rukmana. 1999. Budidaya Cacing Tanah. Kanisius. Yogyakarta.

Sihombing, D. T. H. 2002. Satwa Harapan 1 Pengantar Ilmu dan Teknologi Budidiya. Pustaka Wirausaha Muda, Bogor.
Sugiantoro, A. 2012. Budidaya Cacing Tanah untuk Obat Alternatif Cetakan Pertama. Dafa Publising. Yogyakarta.

Swardjono. 2000. Analisis Macam dan Ketebalan Limbah Organik untuk Budidaya Cacing Tanah. Laporan Penelitian. Lembaga Penelitian. Universitas Terbuka. Yogyakarta.

Waluyo, D. 1993. Pengaruh Kapur terhadap Perkembangan Tubuh dan Klitelium serta Kadar Protein dan Asam Amino pada Cacing Tanah Esenia foetida savigny. Program Pasca Sarjana Institut Pertanian Bogor. Bogor.

Yinosumarto, S. 1993. Perancangan Percobaan, Analisis dan Interprestasinya. Gramedia Pustaka Umum, Yogyakarta. 